\title{
Evaluation of land cover / land use development in selected landscape conservation areas in comparison to non-protected areas
}

\author{
LUCIA BENDÍKOVÁ ${ }^{1,2}$, MARKÉTA ŠANTRŮČKOVÁ ${ }^{2}$ ZDENĚK LIPSKÝ1
}

\footnotetext{
${ }^{1}$ Charles University, Faculty of Science, Prague, Czechia; e-mail: bendikova@vukoz.cz, lipsky@ natur.cuni.cz

${ }^{2}$ Silva Tarouca Research Institute for Landscape and Ornamental Gardening, Průhonice, Czechia; e-mail: bendikova@vukoz.cz,santruckova@vukoz.cz
}

ABSTRACT Qualities of protected areas in Europe are the result of mutual collaboration, and the influence of natural conditions and historical development. Therefore, landscape protection has a wider scope. In addition to the protection of the landscape's natural qualities, landscape protection also needs to identify human-driven impacts that support or directly affect landscape qualities. We have compared the development of land use / land cover in selected landscape conservation areas, and suitably selected referential areas in four time levels within a period of more than 150 years. The goals were to identify the types of land use that decrease, or increase the qualities of landscape, and to verify the hypothesis that landscape conservation areas, protected areas, have gone through a different land use / land cover development than the referential areas. The results of this comparison do not confirm our hypothesis. The most substantial changes in the rural areas in Czechia took place in a distant past not covered by the dataset used in this study.

KEY WORDS cultural landscape - landscape protection - landscape conservation areas - land cover / land use changes - Czechia

BENDíKOVÁ, L., ŠANTRU゚ČKovÁ, M., LIPSKÝ, z. (2018): Evaluation of land cover / land use Development in Selected Landscape Conservation Areas in Comparison to Non-Protected Areas. Geografie, 123, 3, 295-316.

Received September 2017, accepted June 2018.

CC Česká geografická společnost, z. s., 2018 


\section{Introduction}

Protection of landscape serves to preserve its outstanding features and deals with areas of recognized natural and cultural-historical importance. If we accept the idea that almost the entire territory of Europe has the character of the cultural landscape (Ohnesorge, Plieninger, Hostert 2013), then features of the protected landscape are the result of combined activities of the area's natural characteristics and historical development with significant human influence. In many cases, human activity influenced the area in a positive way promoting its outstanding qualities or even directly creating them, while also helping to create conditions for its later protection.

Unlike untransformed landscape, protection of cultural landscape expands its scope in the context of wider ecosystem with regard to the relations between local communities and their heritage, humanity and its natural environment (Rössler 2006; Olah, Boltižiar 2009; Muntanu et al. 2017). In the landscape where the borders between the original, untransformed, landscape and the landscape transformed by man are still visible, the protection objective is to minimize both the land cover / land use changes and the influence of human activities. However, such borders are "fluid" in the areas which have already undergone fundamental the land cover / land use changes and if there are mutual functional links between the protected and adjacent areas, the protection focus has been shifting from the protected area to the wider multifunctional landscape (Santika, Meijaard, Wilson 2015; Plieninger et al. 2014; Ohnesorge, Plieninger, Hostert 2013; Olah, Boltižiar 2009). The emphasis is on the fact, that such landscape should also sustain other services than the primary ones, i.e. production of primary raw materials (Plieninger et al. 2014), an example of which is the promotion and support of agro-tourism and related activities (Garau 2015).

The land cover / land use is a term which jointly describes mutually linked landscape features; namely, the landscape cover and the landscape utilization by man as one of the important facts influencing the landscape. The land cover / land use describes the representation of studied categories in the area, such as the area composition, and their distribution and fragmentation - area configuration (Mimet et al. 2016). The static formulation of the immediate the land cover / land use situation allows us to evaluate its current state and condition. By inclusion of the time dimension it is possible to obtain a significantly more valid description of the land cover / land use changes development. Some studies go beyond monitoring changes and analyze the processes of the land cover / land use changes, identifying its driving factors and modelling the change (Chang-Martínez et al. 2015, Munteanu et al. 2014); these trends may be identified in e.g. Santika, Meijaard, Wilson (2015); Garau (2015); Ohnesorge, Plieninger, Hostert (2013). The land cover / land use changes details are useful for planning and optimization of the 
landscape utilization therefore a lot of models for the land cover / land use changes description have been created for this purpose. Chang-Martinez et al. (2015) give following division of the land cover / land use changes models.

- According to the time frame, within which the land cover / land use changes are tracked, where we distinguish between the contemporary models (describing approximately the period of last 100 years) and the historical ones (describing long periods, in some cases even stretching back to the Neolithic Revolution).

- According to the approach and methods used at a model creation where we distinguish (1) models based on the pattern (2) models based on agents of changes and (3) hybrid ones using concurrently methods of both groups given above.

In the context of the above given division, the article describes the model analyzing contemporary the land cover / land use changes based on pattern. A considerable part of the processed the land cover / land use changes models uses graphic inputs which are further processed and evaluated. As for the areas analyzed and researched in our study, the descriptive data on the land cover / land use of the studied areas were used as an input.

The range of available the land cover / land use changes data sources is wide and derives from various branches of human activities. The span and availability of the data sources are determined mainly by the features of the studied area and by the time frame within which the land cover / land use changes are studied. The sources used most frequently are the following ones: maps (Valjarevic et al. 2014, Skaloš et al. 2011), aerial photographs of the area (Frate, Carranza 2013; Tekle, Hedlund 2000; Gerard et al. 2010) and outputs of the remote research of the Earth (Bou Kheir et al. 2010; Bagan, Yamagata 2014; Simoniello et al. 2015; Badjana et al. 2015; Hassan et al. 2016) as they provide easily accessible description of the land cover / land use within the studied area in the specific time. It is possible to evaluate the land cover / land use changes simply and relatively exactly through the comparison of such materials created in various time levels. However, such materials are available only in a limited volume as the technologies for the accurate mapping or remote research have been available only for some decades now, and the complex map materials older than 100 years were created only for a small part of the world. Whereas the evaluation of the land cover / land use changes sufficiently proving long-term trends or cycles requires a wider and longer time frame than the one provided by such data, and because, in many cases, it is necessary to evaluate areas, which are situated outside the area of historical mapping, it is of the utmost importance that alternative data sources and methods for their processing be used. There is a wide range of the sources coming from various branches, which can be used for such purposes, e.g. some archaeological findings and historical records (Chang-Martínez et al. 2015, Šantrůčková, Dostálek, Demková 2015) for larger time frames, a map of light smog for determination of urban 
land (Bagan, Yamagata 2014), the area phytodemographical features development and the history of fires as the proof and evidence of slash and burn agriculture (Cuni-Sanchez et al. 2016), but also the land cover / land use changes personal observers statements (Ohnesorge, Plieninger, Hostert 2013) and the like. Such alternative data may be used for refinement of data obtained from the removed research of the Earth (Hoskins et al. 2016).

The registration of land utilization has a long history in the territories of Bohemia and Moravia. In the past, there were various registers documenting the land utilization conducted mostly for the purpose of tax collection. Their continuity may be followed from Berni Rula cadaster of the second half of $17^{\text {th }}$ century to the present Land Registry. At the beginning, such registers used to be kept in the form of texts, later they were supplemented by maps. This continuity in the territory of Czechia enables to document trends and changes in land utilization within large areas quite well (Bičík, Kupková, Štych 2012). However, the application of given materials to smaller areas (e.g. areas in the size of several cadastral areas) carries various difficulties.

The comparison of historical development of land use patterns within the protected and non-protected areas to the comparative natural features can point out how the human activity influences the landscape potential. In case, there are some predominating land use patterns in the protected areas, which are missing in the non-protected areas we can assume that such land use patterns influence the landscape in a positive way in relation to the features determining its protection. Analogically, if it is possible to identify the land use patterns absenting in the protected areas while present in the non-protected areas, it can be assumed that such land use patterns are unfavorable for the landscape. The objective of this study is to verify the validity of the above given hypothesis.

\section{Material and methods}

\subsection{Model areas}

The role of the model protected areas in our study is fulfilled by selected landscape conservation areas. Landscape conservation areas serves for protection and care of the landscape features of given area (Míchal, Löw 2003) and for preservation of its heritage. Objects of interest usually include areas with typical settlements with a minor presence of cultural monuments and historical landscapes with significant cultural value (Kučová 2008) and features of declared landscape conservation areas show that they are usually areas of high architectural values and/or historical (landscape) parks that are closely connected with the open landscape by a composition axis (Kučová, 2008). 
Landscape conservation areas are established by regulations of the Ministry of Culture of the Czech Republic for the purpose of the landscape protection and conservation, and their status and protection range is defined by the Act (No. 20/1987 Coll) on the State Monument Preservation. At the present time, there are 25 landscape conservation areas declared in Czechia. The landscape in landscape conservation areas is the landscape with visible influence and impact of human activity, but concurrently, in most cases, it is the rural area. Such a configuration is preferable and more suitable for verification of the above given assumption than the areas closer to the original landscape (e.g. core zones of national parks) where the influence and impact of the human activity is of such little importance that it is not possible to evaluate its (non)salutariness. On the contrary, the area dominantly urbanized or industrialized would distort the facts and lead to misinterpretation of the evaluation due to the marginal influence of the area landscape conditions whose impact in such a landscape is almost completely suppressed by human activity. Landscape conservation areas represent a proper environment between the original landscape and the landscape which has been changed completely and thus offer the possibility to evaluate the influence and impact of natural landscape conditions and human activity in their mutual symbiosis or compromise. The model landscape conservation areas are Battlefield by Hradec Králové, Chudenicko, Vranovsko - Bítovsko, Zahrádecko and Žehušicko; Fig. 1).

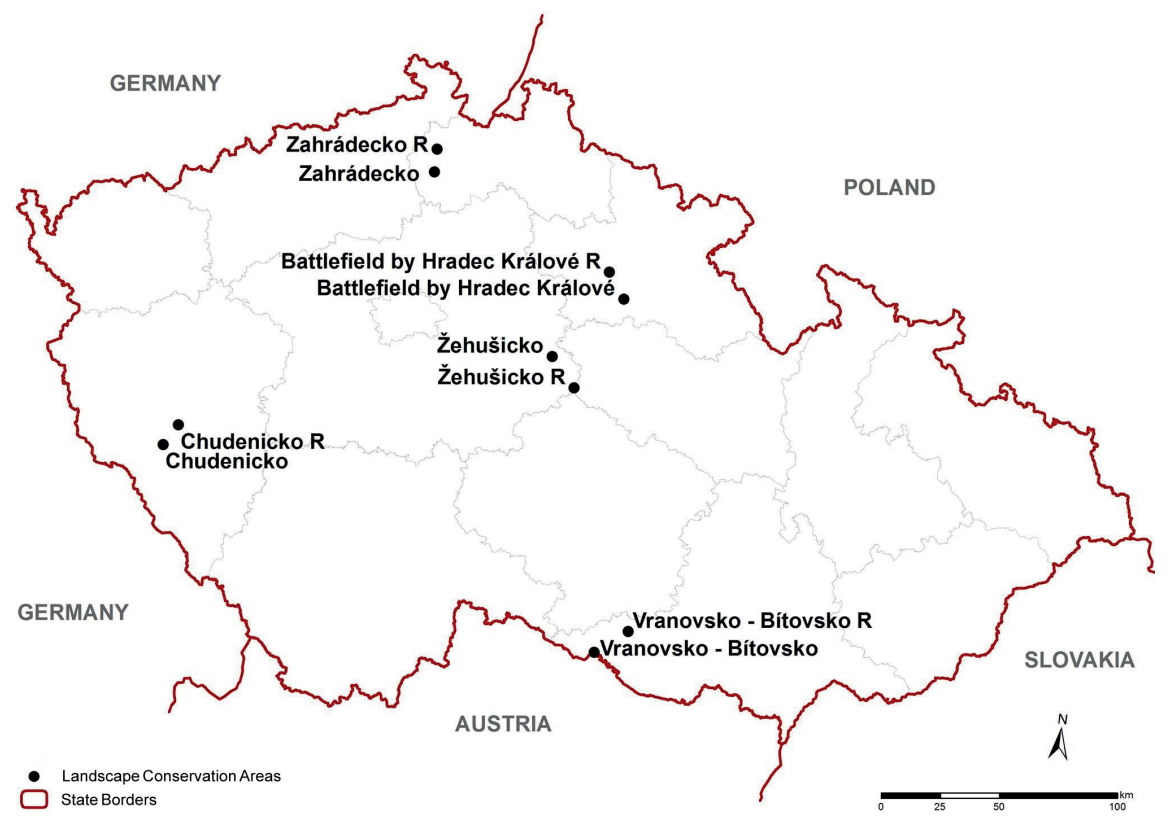

Fig. 1 - The model landscape conservation areas and the reference areas 
To prove our hypothesis we selected a reference area of the same size situated in the landscape with similar natural features for each landscape conservation area. The similarity of natural features was determined by means of the landscape typology by Kolejka (Hrnčiarová et al. 2009) and by hypsometric curve (Fig. 1).

\subsection{Data characterization}

For the purposes of this article we used the following data sources:

- Gemeindelexikons: Gemeindelexikon von Böhmen (1904), Gemeindelexikon von Mähren (1906), Gemeindelexikon von Niederösterreich (1903)

- aggregated values of land use for years 1845 and 1948

- recent statistical data provided by the land registry

These are the most complex data files available for Bohemia and Moravia describing in complexity types of land, ways of land use and land use changes. Data from the above given sources describe the development and changes of land use in the time span of more than one and a half century in four time levels (1845 - aggregated values of land use, 1900 - data from Gemeindelexikons, 1948 - aggregated values of land use and 2016 - data obtained from the Land Registry). These data are descriptive evidencing the area composition well, however, they do not allow a closer view to the area configuration (Mimet et al. 2016). Therefore, it is necessary to take the above given fact into consideration when evaluating.

The borders of administrative units, to which the descriptive data obtained from the sources relate, are determined on the basis of the following map sources:

- Stable cadastral maps

- Gemeindelexikons

- Map operator of the Land Registry

\subsection{Limits of data continuity}

Utilization of the selected data set for description of changes and development of land use within the model areas in time frame has its limits, and it is important to deliberate them in the course of data processing.

Historical changes in organization of the area represent the first problem for data collection. The territories of Bohemia and Moravia underwent a turbulent political development during the determined time frame. Fall of the Habsburg Monarchy, changes of circumstances after World War II and also other, less important events, introduced various changes in administrative organization. The areas, to which the collected land use data relate, are not identical in all time levels, and their borders differ. 
The attitude to the purpose of the land use information changed in the course of time what influenced the structure of the collected data. These are, in some time levels, organized into different land use categories. Landscape conservation areas, as areas of interest, are limited by borders corresponding with their purpose stipulated by the Act on the State Monument Preservation (20/1987 Coll.). This purpose is not identical with the purpose of administrative structure of the model areas and therefore the borders of the studied areas do not correspond with the borders of administrative units. In our research, the administrative units are represented by the cadastral areas.

Prior the evaluation of the processed data, it was necessary to reduce the influence of the above given problems to the results of the study.

\subsubsection{Changes of cadastral areas}

In the course of the studied period, the administrative structure and organization were transformed and changed many times. The cadastral areas were united into larger ones, divided into smaller ones or their borders were changed while their number stayed untouched. In such cases, data for individual time levels did not relate to the identical areas.

The issue of comparability of data on land use in Czechia in different time levels was studied and analyzed within the project LUCC Czechia. In the frame of the above mentioned project, performed at the Czechia Land Use Changes Research Centre of the Charles University in Prague, the territory of Czechia and Moravia was organized into so called Basic Territorial Units (BTU). BTUs are the territorial units proposed to ensure comparability across all time horizons despite the changes of borders of administrative units and to create a unique source of information on land use/land cover changes spanning more than one century - the period, when fundamental changes of agricultural production and land use took place in the Czech territory (Bičík et al., 2012). The consolidation of cadastral areas into BTU can lead to creation of units which spread beyond the area of the original cadastral areas markedly, what, in combination with the fact that the borders of landscape conservation areas do not correspond with the borders of cadastral areas, results in serious distortion. Therefore we decided to use the smallest territorial units available and study the area described in the most delicate way. This approach allows more accurate evaluation of data comparability with regard to the facts described below.

\subsubsection{Different border lines of landscape conservation areas and cadastral areas}

The borders of landscape conservation areas and cadastral areas are determined with respect to their specific and different purposes therefore, in many cases, the 
borders of landscape conservation areas do not copy the administrative structure of the territory that is divided into cadastral areas. Landscape conservation areas are usually larger and cover the territory of several cadastral areas. Data on land use in the cadastral area completely included within the borders of landscape conservation areas may be processed without any fears of results misinterpretation. The cadastral areas included into the landscape conservation areas only partly may become a problem. The summary of landscape conservation areas territorial coverage and measure of cadastral areas oversizing are given in the table below. In this case, it is necessary to decide on the fact whether cadastral areas is relevant and provides sufficient and satisfactory data on structure and organization of various types of land parcels within the area of landscape conservation areas. A similar problem is studied in (Šantrůčková, Bendíková 2014), therefore the same criteria for evaluation of the evidencing value of cadastral areas for landscape conservation areas have been chosen:

- Minimum percentage of cadastral areas area covered within the borders of landscape conservation areas is $10 \%$

- The area of cadastral areas within the borders of landscape conservation areas must cover $20 \%$ of the landscape conservation areas in minimum

The above given criteria were applied only for the cadastral areas not completely included into the landscape conservation areas borders (Table 1).

\subsubsection{Differences in data categorization}

In the course of time, data on landscape were collected for various purposes and therefore, in various periods, their organization and categorization differed significantly. Data from Gemeindelexikons have a different structure, and the acreage is given only for such types of land which were subject to taxation. The attachment of taxable areas to the whole acreage of cadastral areas is represented by "unproductive areas" - data aggregate of water surfaces, built-up areas and other areas enumerated in other sources.

The present aggregated values of land use categorization does not distinguish the categories of meadows and pastures separately, but describes them in the joint category of permanent grassland. Analogically, for the needs of comparison, the same category has been created also for older time levels. In contrary to the other time levels, in the present categorization, the categories of hop-field and orchard have been included into the aggregate of permanent cultures. In all time levels, in which they were distinguished, the categories of garden and vineyard have been also included into the same data aggregate. In individual time levels, the categorization of water surfaces is the least unified one. In aggregated values of land use for 1845 , the water surfaces are described in categories of swampland, 
Table 1 - Coverage of the area by landscape conservation areas and measure of cadastral areas oversize outside the borders of landscape conservation areas

\begin{tabular}{lcrcc}
\hline Area & $\begin{array}{c}\text { Size of } \\
\text { landscape } \\
\text { conservation } \\
\text { areas (ha) }\end{array}$ & $\begin{array}{c}\text { Size of } \\
\text { cadastral } \\
\text { areas (ha) }\end{array}$ & $\begin{array}{c}\text { Coverage of landscape } \\
\text { conservation areas by } \\
\text { cadastral areas (\%) }\end{array}$ & $\begin{array}{c}\text { Area of cadastral areas } \\
\text { outside borders of } \\
\text { landscape conservation } \\
\text { areas (\%) }\end{array}$ \\
\hline Battlefield by Hradec Králové & $6,429.76$ & $7,823.58$ & 99.09 & 38.07 \\
Battlefield by Hradec Králové R & $6,429.76$ & $9,350.05$ & 97.64 & 16.54 \\
Chudenicko & $1,656.54$ & $3,136.31$ & 95.67 & 35.07 \\
Chudenicko R & $1,656.54$ & $2,684.60$ & 90.78 & 60.81 \\
Vranovsko - Bítovsko & $7,626.28$ & $9,849.45$ & 95.51 & 52.52 \\
Vranovsko - Bítovsko R & $7,626.28$ & $12,456.88$ & 85.37 & 26.80 \\
Zahrádecko & $2,570.52$ & $4,084.47$ & 99.92 & 53.94 \\
Zahrádecko R & $2,570.52$ & $4,771.35$ & 90.26 & 36.98 \\
Žehušicko & $3,109.63$ & $4,985.29$ & 98.98 & 34.48 \\
Žehušicko R & $3,109.63$ & $4,797.05$ & 97.98 & 40.41 \\
\hline
\end{tabular}

lakes and fishponds (divided into further sub-categories) as still waters and rivers and streams as flowing waters. However, the aggregated values of land use for 1945 distinguishes only stillwater surfaces and flowing waters; rivers and streams are included into the category of other areas. In the present data, it is possible to distinguish still waters (with sub-categories of fishpond, natural water reservoir, artificial water reservoir, water-logged soil and water surface with a building) and flowing waters (with sub-categories of natural water flow and artificial water flow). Therefore, for proper interpretation of development of water surfaces in time levels of 1900 and 1945, it is essential that the data set be completed by data from other sources.

In this article distinguished are following categories:

- arable land

- permanent cultures (in present aggregated values of land use they include also gardens, hop-fields, vineyards and orchards)

- permanent grassland (in 1845, 1900 and 1948 consisting of meadows and pastures)

- forests

- stillwaters (the unproductive areas for 1896)

- flowing waters (the unproductive areas for 1896 and other areas for 1948)

- built-up areas (the unproductive areas for 1986)

- other surfaces (the unproductive areas for 1896). 


\subsection{Data processing}

The processed data set consists of size of individual land use categories for each cadastral areas, which spreads into the borders of landscape conservation areas, and which have been evaluated as relevant according to the specified criteria. The relevancy of individual cadastral areas has been determined by analytical tools of ArcGIS program. We summed up the size of individual categories for each landscape conservation areas through all included cadastral areas and we obtained the information on its representation in the area of landscape conservation areas. This enumeration of representation characterizes the area of landscape conservation areas as a whole in exclusively descriptive way, non-reflecting and non-describing the spatial distribution and configuration of these categories. For such a characteristic it is necessary the descriptive data to be compared to the proper map materials what has not been the aim of this article and research.

The summed up data have been organized into the review tables for each landscape conservation areas and their representation in diagrams enables the interpretation of development and changes in land use in the course of time. The land cover / land use changes have been compared in the frame of couples represented by landscape conservation areas and their reference areas.

\section{Results}

The summarized data have been evaluated and the land cover / land use changes development trends have been determined for each couple of landscape conservation areas and its reference area individually.

\subsection{Battlefield by Hradec Králové}

Both areas show stability in the course of the studied period (Fig. 2 and 3). The most significant change in both areas is represented by decrease of permanent grassland (by $5.56 \%$ in the area of landscape conservation area Battlefield by Hradec Králové and by $6.61 \%$ in the reference area). It specific that, in this case, there is the higher representation of arable land in the landscape conservation area Battlefield by Hradec Králové than in the reference area and, on the other hand, the lower representation of forests in the area of landscape conservation area Battlefield by Hradec Králové than in the reference area. In the other studied areas this trend develops contrariwise. 


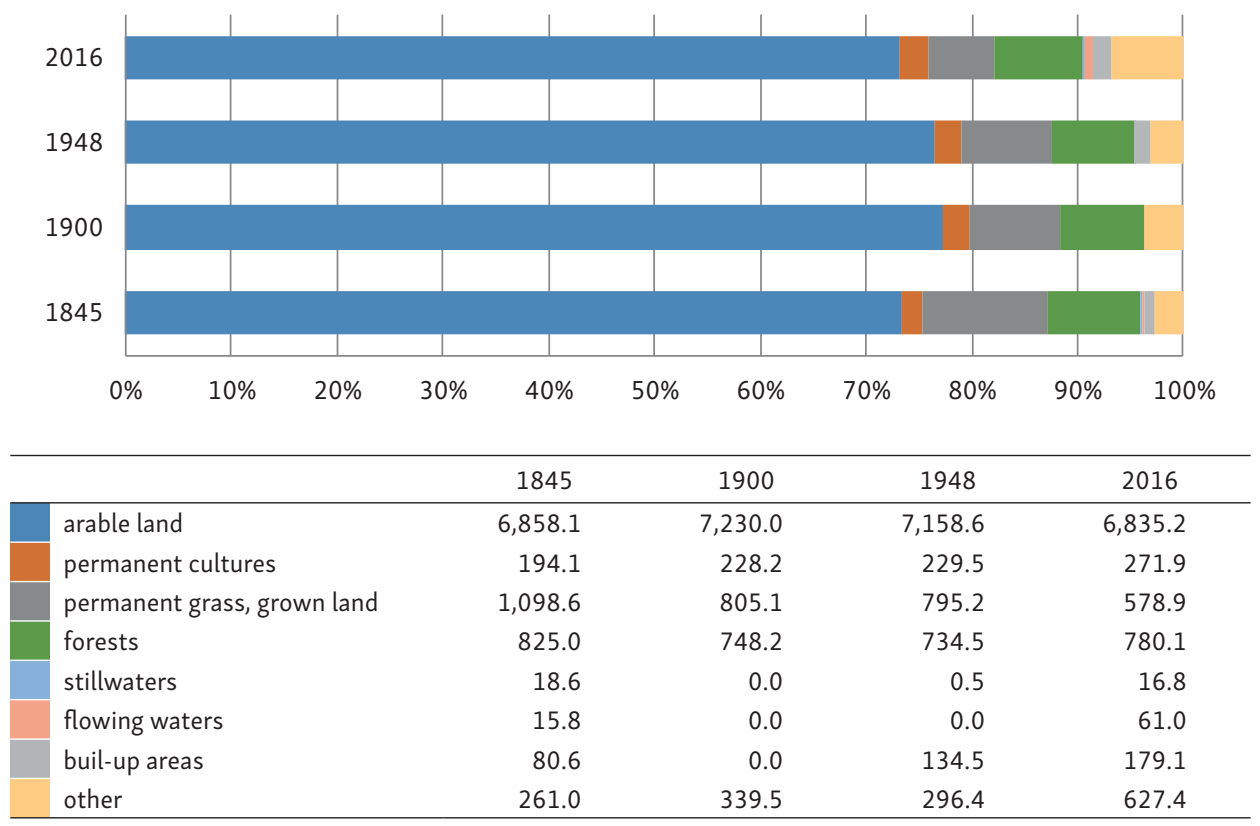

Fig. 2 - Land use changes in the landscape conservation area Battlefield by Hradec Králové (in ha)

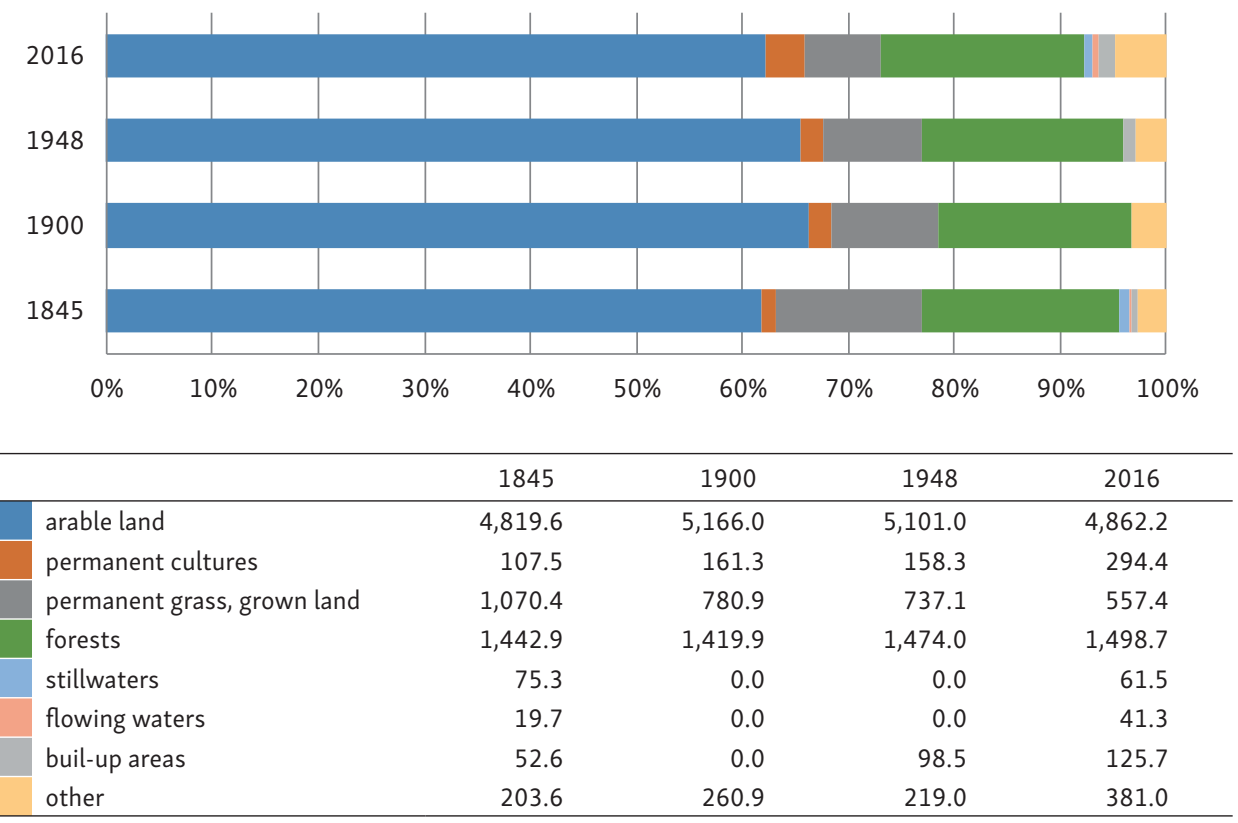

Fig. 3 - Land use changes in the reference area to the landscape conservation area Battlefield by Hradec Králové (in ha) 


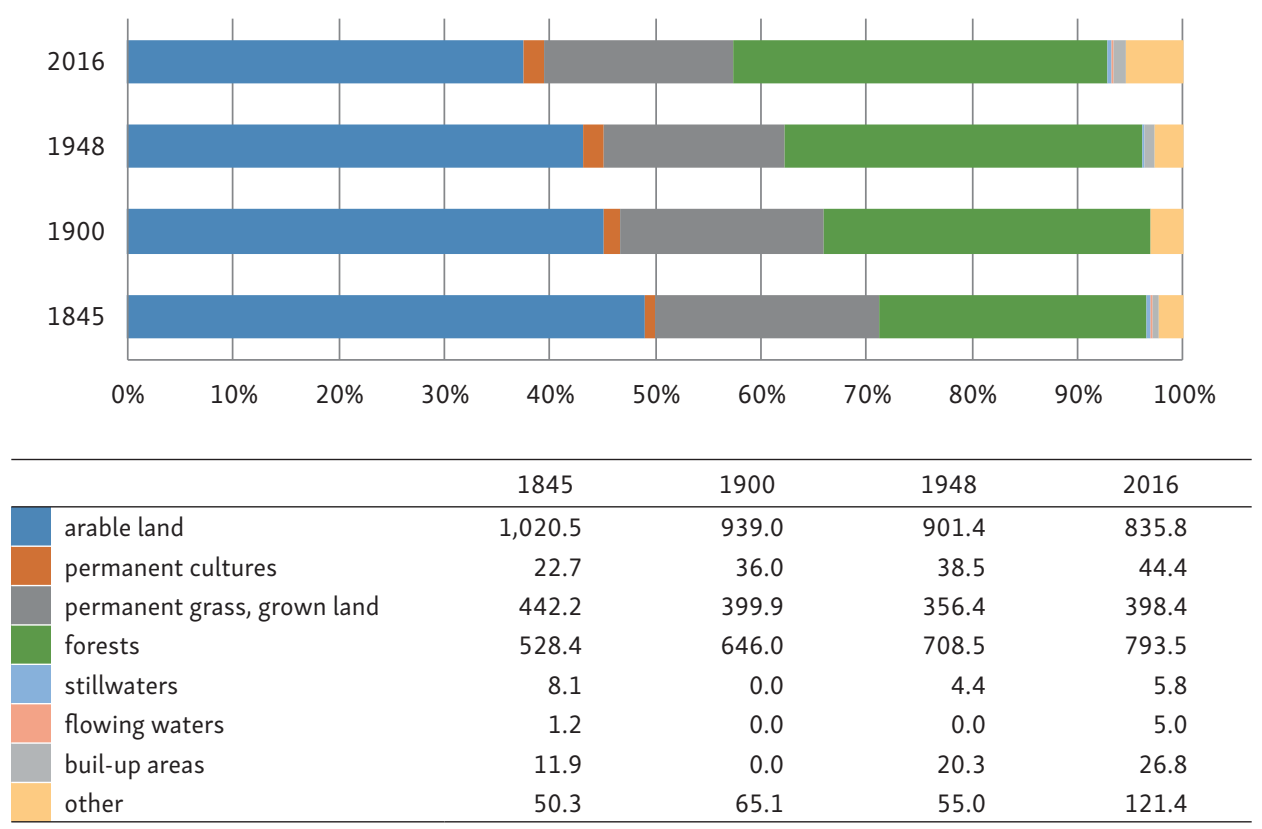

Fig. 4 - Land use changes in the landscape conservation area Chudenicko (in ha)

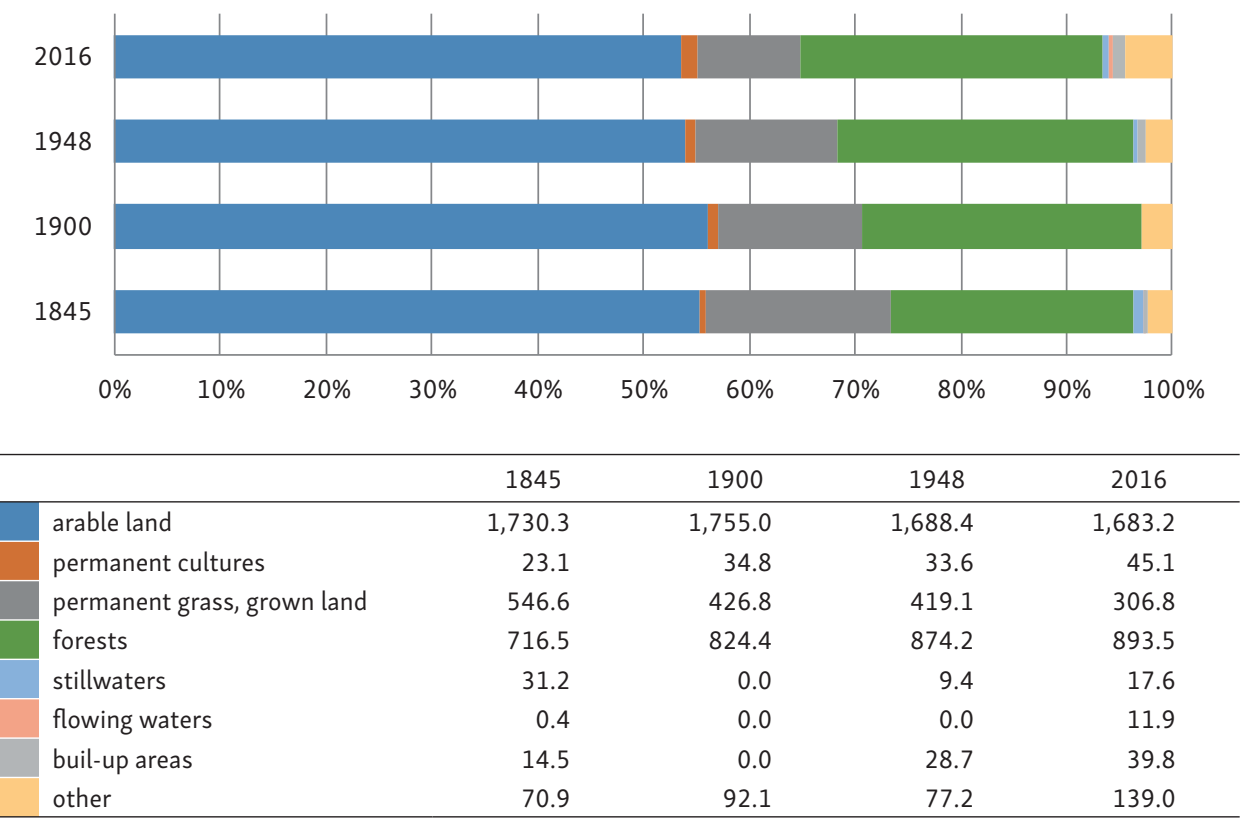

Fig. 5 - Land use changes in the reference area to the landscape conservation area Chudenicko (in ha) 


\subsection{Chudenicko}

The most significant change in the area of Chudenicko landscape conservation areas (Fig. 4) is represented by decrease of representation of arable land by $11.48 \%$, which is evident in the course of whole studied period, with the most apparent decrease between 1948 and 2016 time levels. The representation of the forests area shows the opposite development, the continual increase of $10.23 \%$ during the studied period with the most significant decrease between 1845 and 1900 time levels. The reference area shows the higher stability in the course of the studied period, with the most evident change in ratio of permanent grassland decreased of $7.66 \%$ (Fig. 5).

\subsection{Vranovsko - Bítovsko}

Both the area of Vranovsko - Bítovsko landscape conservation areas and its reference area (Fig. 6 and 7) show the stability in the course of the studied period. The maximum changes of the land cover / land use, of less than 10\% between individual studied periods, were observed in the categories of arable land, permanent grassland, forests and other areas. There was a significant change in the area of landscape conservation areas in the representation of stillwaters between 1845 and 1948 time levels caused by construction of Vranov dam (1930-1934). Except for this category, the trends of changes are almost identical in both compared areas with their decrease of arable land and permanent grassland ratio and concurrent increase of forests and other areas ratio.

\subsection{Záhradecko}

In the area of Záhradecko landscape conservation areas (Fig. 8), the category of arable land changed in the course of the studied period from the original $45.03 \%$ in 1845 , with a slight increase in 1900 , and then its ratio was decreasing continually as low as to the present $29.50 \%$. This decrease is compensated by the increase of forests area (approximately by 6\%) and stillwaters area (approximately by $8 \%$ ). In the course of the studied period, the reference area (Fig. 9) shows a similar development of changes, but in a less remarkable measure. The most significant difference, in the contrary to the reference area, is the increased area of stillwater surfaces in the territory of Záhradecko landscape conservation areas, significant for its fishing management and the largest historical system of fishponds in the Northern Bohemia (Kuča et al. 2015). However, the ambiguity of stillwaters categorization described in chapter 2.2.3 must be taken into account and the significant 


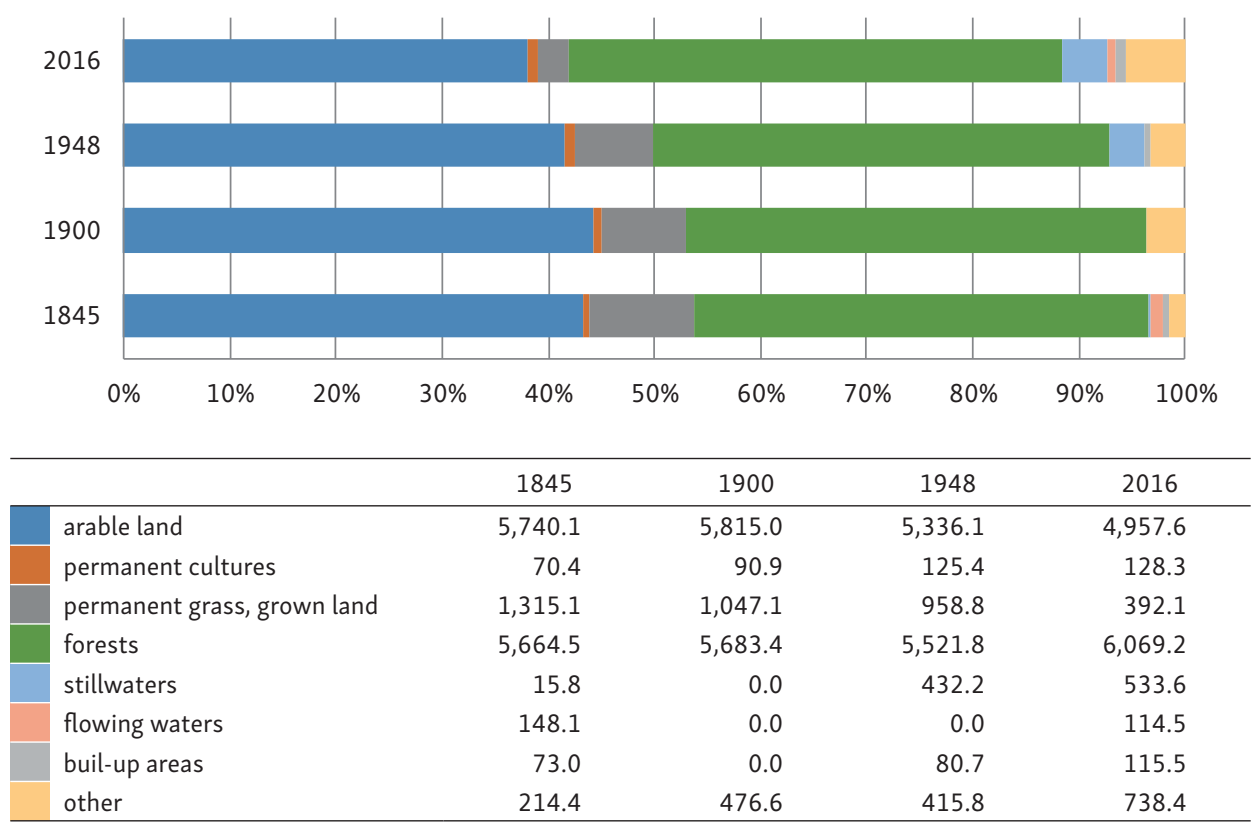

Fig. 6 - Land use changes in the landscape conservation area Vranovsko - Bítovsko (in ha)

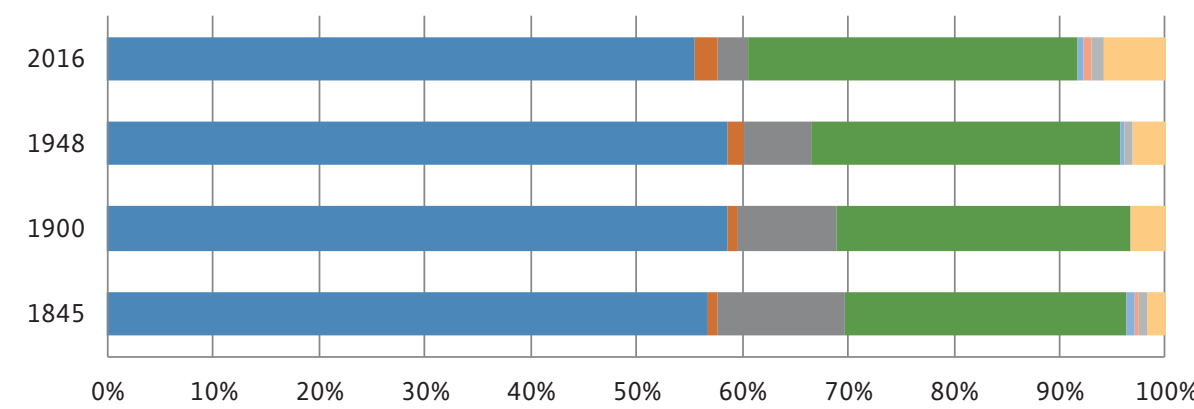

\begin{tabular}{lrrrr}
\hline & 1845 & 1900 & \multicolumn{1}{c}{1948} & \multicolumn{1}{c}{2016} \\
\hline arable land & $5,598.8$ & $5,789.0$ & $5,782.7$ & $5,476.4$ \\
\hline permanent cultures & 88.2 & 96.8 & 148.6 & 193.9 \\
permanent grass, grown land & $1,190.7$ & 918.6 & 638.2 & 289.2 \\
forests & $2,619.6$ & $2,737.9$ & $2,880.4$ & $3,061.9$ \\
stillwaters & 84.1 & 0.0 & 39.7 & 63.0 \\
flowing waters & 42.2 & 0.0 & 0.0 & 69.4 \\
buil-up areas & 73.6 & 0.0 & 76.4 & 122.8 \\
other & 170.1 & 319.7 & 302.5 & 573.4 \\
\hline
\end{tabular}

Fig. 7 - Land use changes in the reference area to the landscape conservation area Vranovsko - Bítovsko (in ha) 


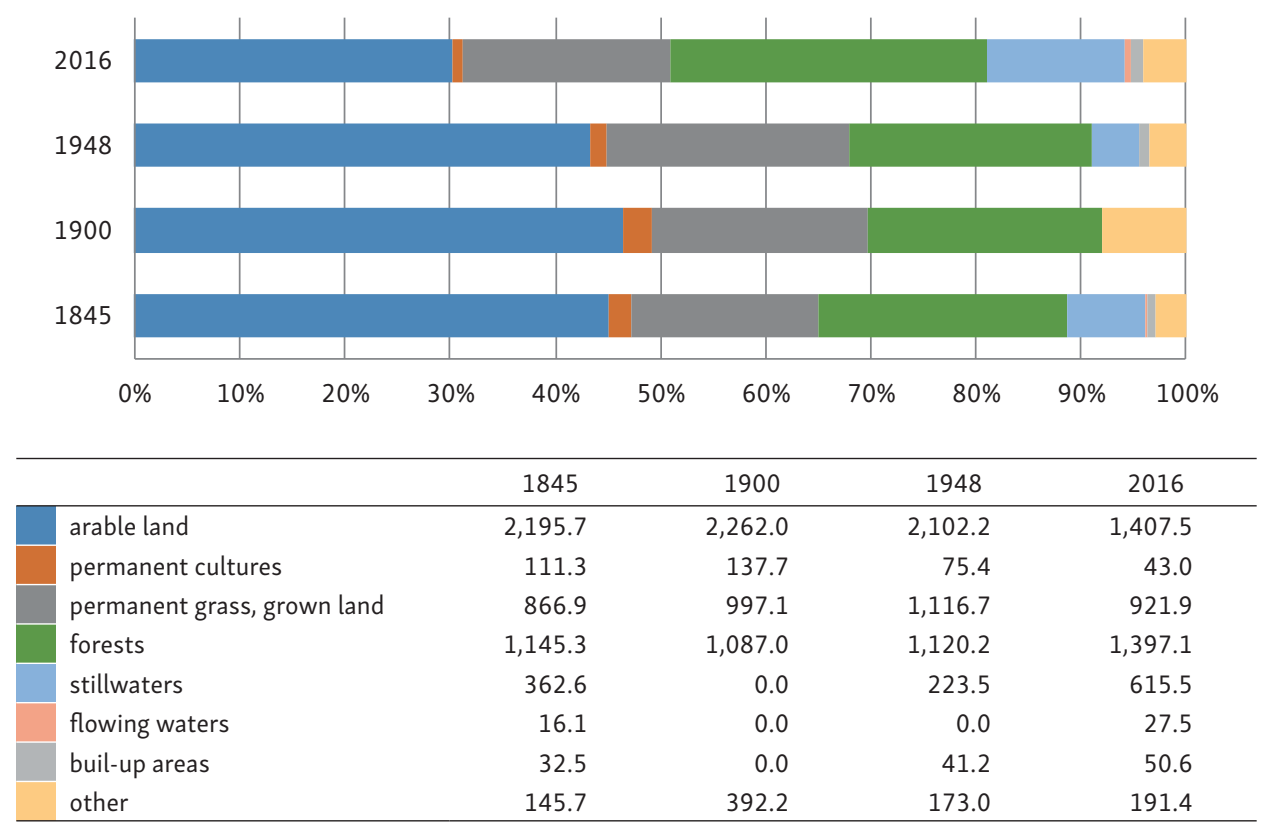

Fig. 8 - Land use changes in the landscape conservation area Zahrádecko (in ha)

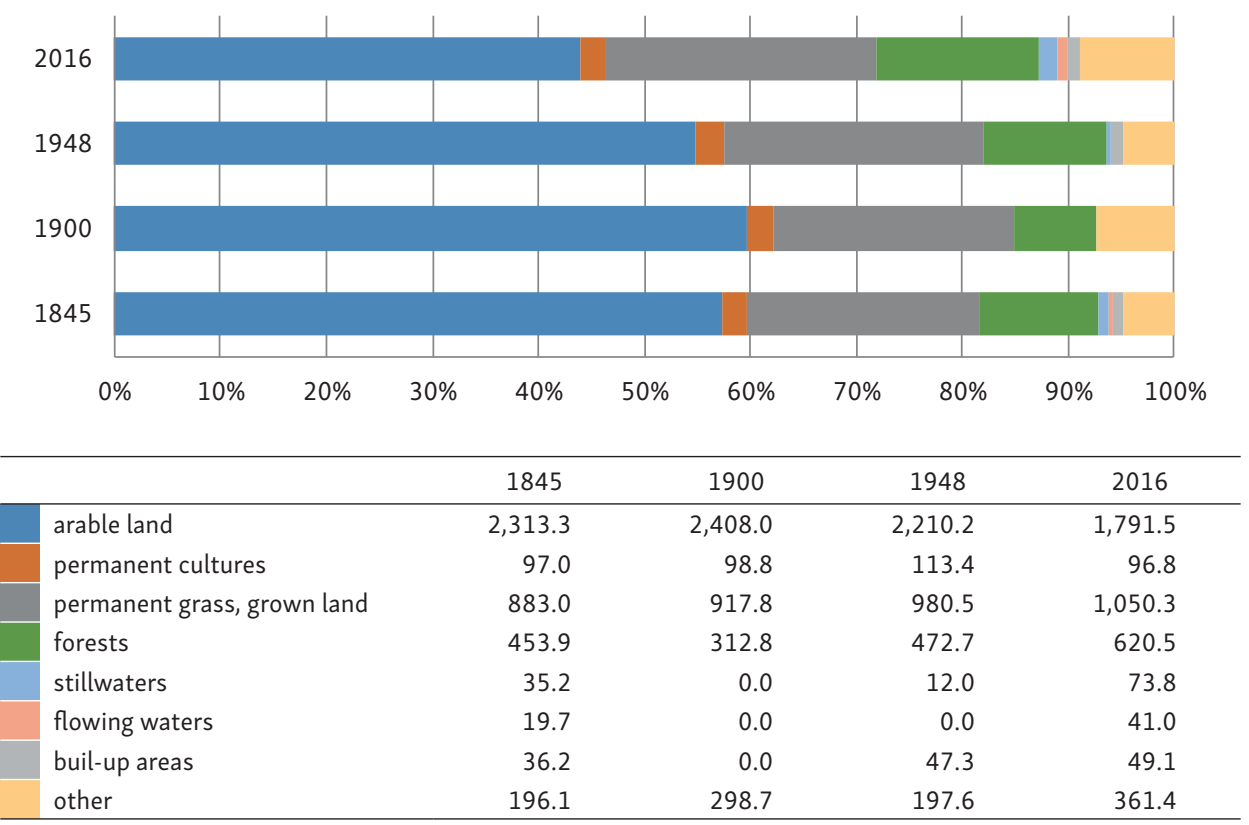

Fig. 9 - Land use changes in the reference area to the landscape conservation area Zahrádecko (in ha) 


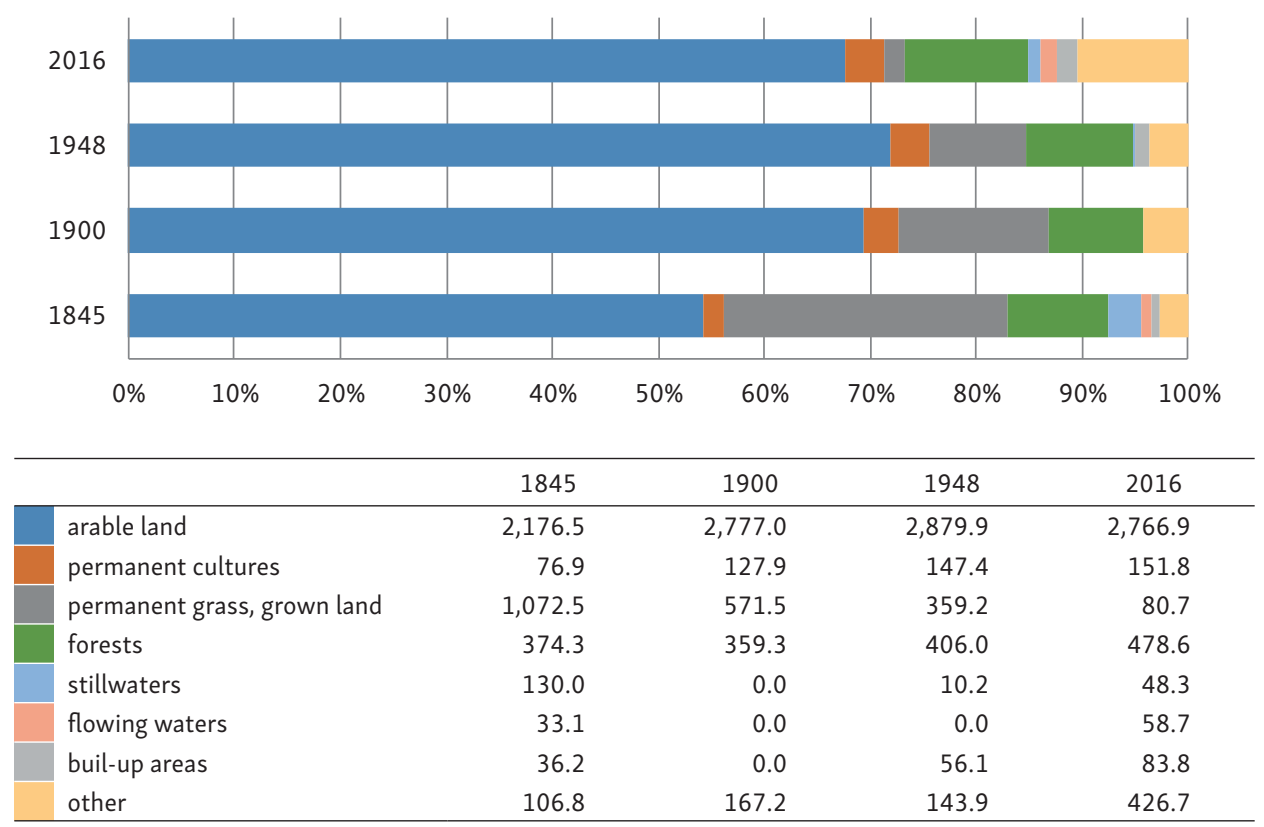

Fig. 10 - Land use changes in the landscape conservation area Žehušicko (in ha)

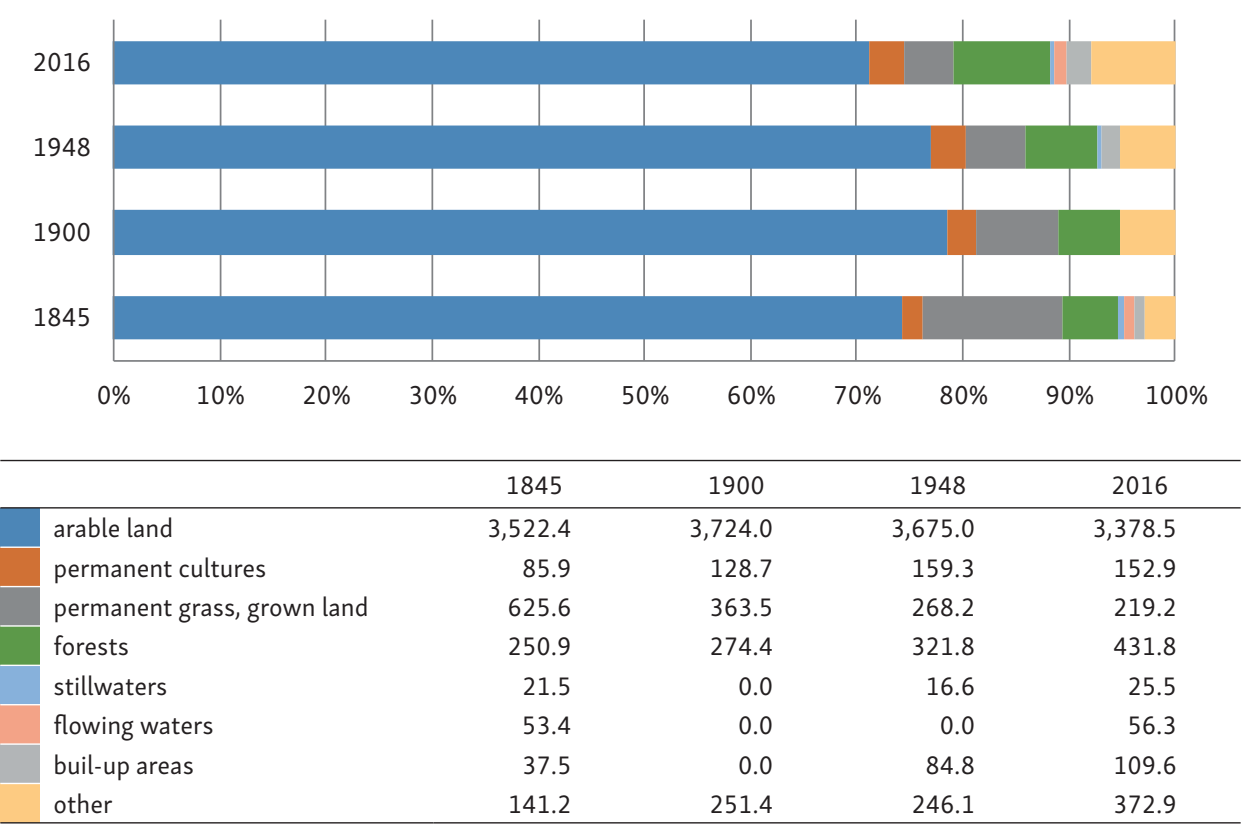

Fig. 11 - Land use changes in the reference area to the landscape conservation area Žehušicko (in ha) 
increase of this category area should be considered the result of errors and differences in categorization.

\section{5. Žehušicko}

In the course of the studied period, the area of Žehušicko landscape conservation areas underwent notable changes (Fig. 10). The permanent grassland, which covered more than a quarter of the area in 1845, disappeared almost completely (decrease from $26.77 \%$ to the present 1.97\%), the area of arable land increased from $54.33 \%$ in 1845 by $13.23 \%$, with the highest increase between 1845 and 1900 , when the area of arable land increased by $15.05 \%$. The increase of other surfaces by $7.75 \%$ is also remarkable. Decrease in the representation of permanent grassland can be observed also in the reference area (Fig. 11), however, it is not so obvious, and the permanent grassland ratio in the reference area is $4.62 \%$. The land cover / land use changes development of the other categories in the reference area is more stable.

\subsection{General evaluation of studied areas}

The evaluated data show that, with exception of several changes in individual categories, the landscape conservation areas and their reference areas have very similar features. In all cases, it is the agricultural landscape with the most significant representation of arable land ranging from approximately $30 \%$ to approximately $70 \%$ where, in all areas, the identical trend of a slight decrease and the jump increase of the arable land area between 1845 and 1900 can be observed. Except for the area of landscape conservation area Battlefield by Hradec Králové, the ratio of arable land in all landscape conservation areas is lower than in reference areas of approximately $10 \%$. With the exception of Zahrádecko landscape conservation area, the second largest category is the one of forests followed by permanent grassland. The forest areas are larger in the landscape conservation areas. Whereas all studied areas are situated in the rural areas with the minimum extend of urbanization, the ratio of built-up area and other areas is low.

\section{Discussion}

The article describes and mutually compares development of five couples of areas with similar natural features; one area of each couple is protected as the landscape conservation area. The evaluated data have not shown any trends in 
the land cover / land use changes development of given areas suggesting the area development into valuable or, on the contrary, into little important or even damaged landscape. The area couples have been selected on purpose, with similar ratio of influence of natural features and impacts of human activity. The landscape conservation areas and their reference areas share similar the land cover / land use changes development resulting from their mutual geographical neighbourhood. The studied areas are situated in the rural area, outside the expansion of bigger towns into the landscape, and they have not been reached by strong suburbanization typical for the suburban landscape in the course of the studied period (Bagan, Yamagata 2014; Tekle, Hedlund 2000; Simoniello et al. 2015; Badjana et al. 2015; Hassan et al. 2016; Gerard et al. 2010). Reduction of arable land corresponds with contemporary trends, however, in the studied areas; such decrease is replaced by increase of forests or permanent grassland (Munteanu et al. 2014). The common features of the studied areas, which designated their valuability and listing in the preservation system, are represented by their stability in the course of the studied period and preservation of the balanced ratio of natural and cultural landscape.

In comparison to the present state and development of the land cover / land use changes in the whole territory of Czechia, it is obvious that the ratio of arable land in the studied areas is higher, represented on the level of average value for the whole Czechia (Souhrnné prehledy 2016), or even markedly higher above the average (with approximately $70 \%$ in the area of landscape conservation area Battlefield by Hradec Králové). The ratio of forests in individual areas differs from notably below the average when compared to the whole territory of Czechia (Souhrnné prehledy 2016); (landscape conservation area Žehušicko, landscape conservation area Battlefield by Hradec Králové) to the highly above average (landscape conservation area Vranovsko - Bítovsko). All the areas copy the trend of a slight increase of the area forestation typical for the territory of Czechia (Kabrda, Bičík 2010).

The results of our study correspond with the results described in Ohnesorge et al. (2013), where a similar topical view was used in relation to the region of the Central Europe. It supports the idea that, in the context of cultural landscape, the protected areas represent a part of the socio-economic systems created on the long-term basis (Ohnesorge, Plieninger, Hostert 2013) with the influence spreading from the borders of the preserved areas into the surrounding landscape and vice-versa. Such a landscape fulfils wider spectrum of services than the ordinary ecosystem and it can be taken as the socio-ecological systems ( $\mathrm{Gu}$, Subramanian 2014, Huntsinger, Oviedo 2014).

We also verified the usability of exclusively descriptive data on the area for evaluation of the land cover / land use changes in the course of time. Their use has its limits as they describe only the composition of the land cover / land use of the area. The changes in configuration enabling a more accurate analysis of the land cover / land use changes trends are described, for example, in Ohnesorge, 
Plieninger, Hostert. (2013). Therefore most of the land cover / land use changes researches are based on graphic materials (Cuni-Sanchez et al. 2016; Frate, Carranza 2013). However, these data limit the time span of the land cover / land use changes evaluation to the period of available technologies enabling collection of necessary data and execution of such material, as it is obvious in the above mentioned studies not covering the period older than a half of the twentieth century. The evaluation of the given period is satisfactory accurate when developing regions or surroundings of big towns which underwent the fast and dramatic evolution in the given period are evaluated. The areas described in our study have shown the stability with the minimum changes within the studied period what is the result of their location and the long-term human activity. These areas faced their most significant changes in the deeper past. For the overall understanding of the dynamics of development of such areas it is necessary to describe the land cover / land use changes in a wider time frame and to search possibilities and methods for use of alternative source data.

\section{Conclusion}

The landscape conservation areas are the only formal units in the territory of Czechia, which may act in the legislation of the cultural landscape preservation (Kuča et al. 2015) and as such they have the potential to fulfil the function of so called "core zones" of the cultural landscape preservation. Sustainable management of these areas must reflect their multifunctionality and existing links with wider socio-economical system. The evaluation of the land cover / land use changes is a strong tool for analysis of impacts of human activity. In the context of European landscape, the larger part of which has already undergone its significant changes, it is of material importance to enlarge the land cover / land use changes monitoring time frame beyond the frame of available graphic information on given area. A wide scale of information sources evidencing the land use and describing the area development for two or three centuries is available for the territory of Czechia and with proper methods it will be possible to use these data for description of development not only of the landscape composition but also of the landscape configuration.

\section{References}

BADJANA, H. M., HELMSCHROT, J., SELSAM, P., WALA, K., FLÜGEL, W.-A., AFOUDA, A., AKPAGANA, K. (2015): Land cover changes assessment using object-based image analysis in the Binah River watershed (Togo and Benin). Earth and Space Science, 2, 10, 403-416. 
BAGAN, H., YAMAGATA, Y. (2014): Land-cover change analysis in 50 global cities by using a combination of Landsat data and analysis of grid cells. Environmental Research Letters, 9, 6.

BIČÍK, I., KUPKOVÁ, L., ŠTYCH, P. (2012): Changes of Land Use Structure in Czechia: From Local Patterns to a More Complex Regional Organization. Land Use/Cover Change in Selected Regions in the World, 7, 5-12.

BOUKHEIR, R., BØCHER, P.K., GREVE, M.B., GREVE, M.H. (2010): The application of GIS based decision-tree models for generating the spatial distribution of hydromorphic organic landscapes in relation to digital terrain data. Hydrol. Earth Syst. Sci., 14, 6, 847-857.

CHANG-MARTÍNEZ, A.L., MAS, J.-F., VALLE, T.N., TORRES, S.P., FOLAN, J.W. (2015): Modeling Historical Land Cover and Land Use: A Review fromContemporary Modeling. ISPRS International Journal of Geo-Information, 4, 4, 1791-1812.

CUNI-SANCHEZ, A., WHITE, L.J.T., CALDERS, K., JEFFERY, K.J., ABERNETHY, K., BURT, A. et al. (2016): African Savanna-Forest Boundary Dynamics: A 20-Year Study. PLOS ONE, 11, 64.

FRATE, L., CARRANZA, L.M. (2013): Quantifying Landscape-Scale Patterns of Temperate Forests over Time by Means of Neutral Simulation Models. ISPRS International Journal of Geo-Information, 2, 1, 94-109.

GARAU, C. (2015): Perspectives on Cultural and Sustainable Rural Tourism in a Smart Region: The Case Study of Marmilla in Sardinia (Italy). Sustainability, 7, 6, 6412-6434.

Gemeindelexikon von Böhmen (1904): bearbeitet auf Grund der Ergebnisse der Volkszählung vom 31. Dezember 1900, 1. Teil / hrsg. von der K.K. statistischen Zentralkommission. Alfred Hölder, Wien.

Gemeindelexikon von Mähren (1906): bearbeitet auf Grund der Ergebnisse der Volkszählung vom 31. Dezember 1900 / hrsg. von der K.K. Statistischen Zentralkommission. K.K. Hof- und Staatsdruckerei, Wien.

Gemeindelexikon von Niederösterreich (1903): bearbeitet auf Grund der Ergebnisse der Volkszählung vom 31. Dezember 1900. 1, Niederösterreich / hrsg. von der k.k. statistischen Zentralkommission. Alfred Hölder, Wien.

GERARD, F., PETIT, S., SMITH, G., THOMSON, A., BROWN, N., MANCHESTER, S,. WADSWORTH, R., BUGAR, G., HALADA, L., BEZÁK, P., BOLTIŽIAR, M., DE BADTS, E., HALABUK, A., MOJSE, M., PETROVIC, F., GREGOR, M., HAZEU, G., MÜCHER, C.A., WACHOWICZ, M.,HUITU, H., TUOMINEN, S., KÖHLER, R., OLSCHOFSKY, K., ZIESE, H., KOLAR, J., SUSTERA, J., LUQUE, S., PINO, J., PONS, X., RODA, F., ROSCHER, M., FERANEC, J. (2010): Land cover change in Europe between 1950 and 2000 determined employing aerial photography. Progress in Physical Geography, 34, 2, 183-205.

GU, H., SUBRAMANIAN, S.M. (2014): Drivers of Change in Socio-Ecological Production Landscapes: Implications for Better Management. Ecology and Society, 19, 1, 41.

HASSAN, Z., SHABBIR, R., AHMAD, S.S., MALIK, A.H., AZIZ, N., BUTT, A., ERUM, S. (2016): Dynamics of land use and land cover change (LULCC) using geospatial techniques: a case study of Islamabad Pakistan. SpringerPlus, 5, 1, 812.

HOSKINS, A.J., BUSH, A., GILMORE, J., HARWOOD, T., HUDSON, L.N., WARE, C., WILLIAMS, K.J., FERRIER, S. (2016): Downscaling land-use data to provide global 30" estimates of five land-use classes. Ecology and Evolution, 6, 9, 3040-3055.

HRNČIAROVÁ, T. et al. (2009): Landscape atlas of he Czech Republic. The Silva Tarouca Research Institute for Landscape and Ornamental Gardening, Průhonice.

HUNTSINGER, L., OVIEDO, J.L. (2014): Ecosystem Services are Social-ecological Services in a Traditional Pastoral System: the Case of California's Mediterranean Rangelands. Ecology and Society, 19, 1, 8. 
KABRDA, J., BIČÍK, I. (2010): Dlouhodobé změny rozlohy lesa v Česku i ve světě. Geografické rozhledy, 20, 1, 2-5.

KUČA, K. et al. (2015): Krajinné památkové zóny České republiky. Národní památkový ústav, Praha.

KUČOVÁ, V. (2008): Kulturní krajina a krajinné památkové zóny v České republice v kontextu světového kulturního a přírodního dědictví. Zprávy památkové péče, 68, 4, 295-301.

MÍCHAL, I., LÖW, J. (2003): Krajinný ráz. Lesnická práce s.r.o., Kostelec nad Černými lesy.

MiMeT, A., PELlissier, V., HOUET, T., JULliARD, R., SIMON, L. (2016): A Holistic Landscape Description Reveals That Landscape Configuration Changes More over Time than Composition: Implications for Landscape Ecology Studies. PLOS ONE, 11, 3.

MUNTEANU, C., KUEMMERLE, T., BOLTIŽIAR, M., BUTSIC, V., GIMMI, U., HALADA, L., KAIM, D., KIRÁLY, G., KONKOLY-GYURÓ, E., KOZAK, J., LIESKOVSKÝ, J., MOJSES, M., MÜLLER, D., OSTAFIN, K. OSTAPOWICZ, K., SHANDRA, O., ŠTYCH, P., WALKER, S., RADELOFF, V.C. (2014): Forest and agricultural land change in the Carpathian region A meta-analysis of long-term patterns and drivers of change. Land Use Policy, 38, 685-697.

MUNTEANU, C., KUEMMERLE, T., BOLTIŽIAR, M., LIESKOVSKÝ, J., MOJSES, M., KAIM, D., KONKOLY-GYURÓ, E., MACKOVČIN, P., MÜLLER, D., OSTAPOWICZ, K., RADELOFF, V.C. (2017): Nineteenth-century land-use legacies affect contemporary land abandonment in the Carpathians. Regional Environmental Change, 17, 2209-2222.1

OHNESORGE, B., PLIENINGER, T., HOSTERT, P. (2013): Management Effectiveness and Land Cover Change in Dynamic Cultural Landscapes-Assessing a Central European Biosphere Reserve. Ecology and Society, 18, 4, 23.

OLAH, B., BOLTIŽIAR, M. (2009): Land use changes within the Slovak biosphere reserves zones. Ekológia, 28, 2, 127-151.

PLIENINGER, T., VAN DER HORST, D., SCHLEYER, C., BIELING, C. (2014): Sustaining ecosystem services in cultural landscapes. Ecology and Society, 19, 2, 59.

RÖSSLER, M. (2006): World Heritage cultural landscapes: A UNESCO flagship programme 1992-2006. Landscape Research, 31, 4, 333-353.

SANTIKA, T., MEIJAARD, E., WILSON, K.A. (2015): Designing multifunctional landscapes for forest conservation. Environmental Research Letters, 10, 11.

SIMONIELLO, T., COLUZZI, R., IMBRENDA, V., LANFREDI, M. (2015): Land cover changes and forest landscape evolution (1985-2009) in a typical Mediterranean agroforestry system (high Agri Valley). Nat. Hazards Earth Syst. Sci., 15, 6, 1201-1214.

SKALOŠ, J., WEBER, M., LIPSKÝ, Z., TRPÁKOVÁ, I., ŠANTRŮČKOVÁ, M., UHLÍŘOVÁ, L., KUKLA, P. (2011): Using old military survey maps and orthophotograph maps to analyse long-term land cover changes - Case study (Czech Republic). Applied Geography, 31, 2, 426-438.

Souhrnné přehledy o půdním fondu z údajů katastru nemovitostí České republiky (2016): $1^{\text {st }}$ ed. The Czech Office for Surveying, Mapping and Cadastre, Praha.

ŠANTRŮČKOVÁ, M., BENDÍKOVÁ, L. (2014): Assessment of land use changes in landscape conservation areas based on LUCC database. Land Use/Cover Changes in Selected Regions in the World, 9, 83-93.

ŠANTRŮČKOVÁ, M., DOSTÁLEK, J., DEMKOVÁ, K. (2015): Assessing long-term spatial changes of natural habitats using old maps and archival sources: a case study from Central Europe. Biodiversity and Conservation, 24, 8, 1899-1916.

TEKLE, K., HEDLUND, L. (2000): Land Cover Changes Between 1958 and 1986 in Kalu District, Southern Wello, Ethiopia. Mountain Research and Development, 20, 1, 42-51. 
VALJAREVIC, A., ZIVKOVIC, D., VALJAREVIC, D., STEVANOVIC, V., GOLIJANIN, J. (2014): GIS analysis of land cover changes on the territory of the Prokuplje Municipality. The Scientific World Journal, 2014, Article ID 805072.

\section{ACKNOWLEDGEMENTS}

This research was funded by a long-term research project of the Faculty of Science, Charles University (PRVOUK P43 Geografie) and by institutional support from the Silva Tarouca Research Institute for Landscape and Ornamental Gardening (VUKOZ-IP-00027073). 